\title{
Etiology and Control of Citrus Canker Disease in Kavre
}

\author{
Dinesh Dhakal ${ }^{1}$, Chiranjivi Regmi ${ }^{2}$ and Sital Raj Basnyat ${ }^{1}$ \\ ${ }^{1}$ Central Department of Microbiology, Tribhuvan University Kirtipur \\ ${ }^{2}$ Nepal Academy of Science and Technology, Khumaltar, Lalitpur
}

\begin{abstract}
Citrus canker, caused by the bacterium Xanthomonas citri (Hasse) occurs in large areas of the world's citrus growing countries including Nepal. Though the disease has serious effect in Nepal, this is the first detailed study carried out to isolate the pathogen and confirm it by available biochemical tests and pathogenicity test. Furthermore, the study was intended to find the proper and economical control measure to combat disease in citrus orchards. The causative agent of the disease was isolated from the diseased plants and pure culture was obtained. The isolated pure culture was subjected to Gram staining, catalase test, oxidase test, O-F test, starch hydrolysis, nitrate reduction test, methylred test, Voges-prausker test, indole production test, urease test and carbohydrate utilization test. To re-confirm it, pathogenicity test was conducted on host plant and after the appearance of the typical citrus canker lesion on host, the bacteria was re-isolated, thus proving the Koch's postulates. Different controlling chemicals, copperoxychloride (2.5\%), copperoxychloride + kasugamycin (1000X), bordeaux mixture $1 \%$ and $2 \%$ were sprayed to the plants in citrus orchard at Dhulikhel and the decrease in disease severity after spraying of the chemicals was calculated with reference to the plants that were not sprayed with the chemicals. It was observed that spraying of the chemicals help in decreasing the disease severity. The chemical spray however was not able to eradicate the disease. The study concluded that Xanthomonas citri was the causative agent of the disease citrus canker and copper based chemicals when sprayed very early with the appearance of first symptoms of the disease could eliminate it in citrus fruits to minimum level.
\end{abstract}

Key words: Copper fungicides, citrus canker, Lime, Xanthomonas citri, acid lime, Citrus aurantifolia

\section{Introduction}

In the fiscal year 2004/2005, the total area of citrus cultivation was 25,909 ha out of which 14,606 ha was described as productive area with a total production of $15,956 \mathrm{mt}$ (10.75mt./ha) of fruits. Lime is one of the citrus fruits cultivated in Nepal. In the year 2004/2005, the total production of lime was 19,132 mt (HMG/N ,2004/2005).

Of all the agricultural pests and diseases that threaten lime, citrus canker is one of the most devastating. The disease caused by bacterium Xanthomonas citri (Hasse) occurs in large areas of the world. The disease is endemic in India, Japan and other south-East Asian countries, from where it has spread to all other citrus producing continents except Europe. Considering the high demand of lime in local markets that is being fulfilled by import from IndiaGovernment of Nepal has initiated Citrus (Lime) Mission Programme in Tehrathum, Bhojpur and Dhankuta districts with an objective to substitute the import of this fruits by increasing its production. No detail research has been carried out in Nepal on citrus canker. This study was carried out during 2005 to 2006 in Kavrepalanchowk district as it is representative of most of the hilly districts of Nepal.

Regarding the pathogen of citrus canker, in the late 1980s, strains associated with canker A were proposed as a new species, Xanthomanas citri, whereas types $\mathrm{B}$ and $\mathrm{C}$ as well as other strains causing citrus bacterial spot remained within $X$. campestris as pathovars aurentifolii and citrumelo respectively (Gabriel et al. 1989). Schaad et al. (2000) proposed a 
reclassification that places citrus canker and citrus bacterial spot strains within Xanthomonas as a species citri (A strains), aurantifolli (B and C strains) and citrumelo (citrus bacterial spot strains). However, others authors rejected this new proposal, citing insufficient data to justify the removal of these strains from the species axonopodis ( Vauterin et al. 2000, Young et al.2001).Most recently, Brunings and Gabriel (2003) proposed the retention of $X$. citri as a species that includes only citrus canker strains ( A and B-C)

\section{Materials and Methods \\ Survey}

Survey on canker infestation was carried out in different citrus orchards of Sarada Batase, Khanal Thok and Dhulikhel of Kavrepalanchowk district. In the survey, Citrus plants were checked for the symptoms which include raised, corky, tan lesions with water-soaked margins and yellow halos on the leaves

\section{Disease Status and its severity}

Status of the disease was found out by calculating disease frequency and severity. Disease frequency and severity were calculated by using the following formulae. (Johnston \& Booth 1983)

Disease frequency $=$ Number of infected plants $\times 10$ Total no. of plants

Severity of disease of each sampled plant was calculated by counting the number of leaves showing canker lesion out of total number of leaves sampled.

\section{Disease severity $(\%)=\underline{\text { No. of leaves with lesion }} \times 100$ Total no. of leaves}

\section{Study of pathogen}

Laboratory works were conducted at Nepal Academy for Science and Technology (NAST), Khumaltar, Lalitpur. Leaf samples used for isolation of the bacteria were collected from an orchard of Dhulikhel. Using a sterile razor blade, younger portions of the lesion was cut from a recently collected material. Then a leaf with lesion was taken on a clean microscopic slide and a drop of sterile water was added and observed under oil immersion objective to see streaming bacteria from the edge of leaf. With this characteristic, the isolation procedure was initiated. The cut portion was surface sterilized using $0.1 \%$ mercuric chloride and then washed repeatedly with sterile distilled water, transferred to another sterile plate, minced with a flamed razor in $1 \mathrm{ml}$ of sterile distilled water. It was then allowed to stand for 10-15 min, and then serially diluted up to $10^{-3}$ dilution. Each diluent (0.2) was then spread on the plates on glucose yeast chalk agar (GYCA). The plates were then incubated at $28{ }^{\circ} \mathrm{C}$ for $72 \mathrm{hrs}$. Then suspected mucoid colonies with typical yellow pigment were subjected to Gram staining followed by biochemical and physiological tests. The biochemical tests performed were catalase test, oxidase test, oxidative-fermentative test, methyl Red and Voges-Proskauer tests, indole test, nitrate reduction test and urease test. Similarly carbohydrate utilization test was performed (carried on Dye's medium C) using carbohydrates; arabinose, mannose, galactose, glucose, sucrose, fructose, and sorbitol with incubation of 21 days at $27^{\circ} \mathrm{C}$. For the pathogenicity test, disease free lime saplings were pot cultured. Five plants were assigned for different tests and one plant was assinged for control. Single isolated colony from the 3 day old culture in GYCA was taken and mixed with sterile distilled water to prepare bacterial suspension containing $10^{6}$ $10^{7} \mathrm{CFU} / \mathrm{ml}$ (compared with Mac Ferland's Scale at the suspension at 0.1 to $0.2 \mathrm{ml}$ was inoculated on 3 to 4 points of each leaf. In each test plant 2 to 3 leaves were inoculated with bacterial suspension using $1 \mathrm{ml}$ syringe. Similarly sterile water was inoculated to the plant which served as a control. Inoculated plants were then incubated. Symptoms were observed on leaves after four days of inoculation.

\section{Study of control measures}

For the control of the disease, 5 plots i.e. $1^{\text {st }}, 2^{\text {nd }}, 3^{\text {rd }}, 4^{\text {th }}$ and $5^{\text {th }}$, with five plants in each plots (P1,P2, P3, P4 and P5) were treated with copper oxychloride (2.5\%), copper oxychloride + Kasugamycin (1000X), Bordeaux mixture (1\%), Bordeaux mixture (2\%) and water (control) respectively. Altogether, 5 observations were done, out of which 2 were done before application of the treatments and 3 observations after the treatments of plants with 
respective chemical sprays. Disease severity of the plants before and after each treatment was observed at 15 days interval.

\section{Effectiveness of treatments}

Effectiveness of treatments was determined on the basis of their capacity to reduce disease severity, which was calculated as follows (Table 3 and 4).

Effectiveness $=$ Final disease severity $(5$ th observation i.e. after $3^{\text {rd }}$ treatment) - initial disease

\section{Data Analysis} severity ( $1^{\text {st }}$ observation).

Effectiveness of treatments was compared by LSD (5\%) test.

Table 1. Species of citrus plants infected with citrus canker in the surveyed area

\begin{tabular}{l|c|c|c}
\hline \multirow{2}{*}{\multicolumn{1}{c|}{ Species of citrus plants }} & \multicolumn{2}{|c}{ No. of plants with citrus canker /No. of plant observed } \\
\cline { 2 - 4 } & Dhulikhel & Khanalthok & Saradha Batase \\
\hline C. aurantifolia (Acid lime) & $48 / 55$ & $9 / 9$ & $0 / 0$ \\
C. reticulate (Mandarin orange) & $0 / 0$ & $0 / 15$ & $0 / 72$ \\
C. sinensis (Sweet orange) & $0 / 0$ & $0 / 0$ & $0 / 25$ \\
\hline
\end{tabular}

Results showed that only C. aurantifolia grown in Kavre were susceptible to citrus canker as other species such as $C$. reticulata and $C$. sinensis growing in the vicinity were uninfected. Thus our observation comply with the finding of Civerolo (1984), Graham (1992) and Stall (1993) who reported that acid lime is

\section{Results and Discussion Distribution}

In the orchard of Dhulikhel, only C. aurantifolia was cultivated where out of total 55 plants, 48 were infected with different level of severity and 7 were found uninfected. In Khanalthok, out of 24 citrus fruits cultivated which included C. aurantifolia and $C$. reticulata, only 9 of C. aurantifolia were found infected, though both the fruits were grown in close vicinity. In Saradha Batase, a total of 97 citrus plants were observed which included $C$. reticulata and $C$. sinensis and none of them were infected with the disease citrus canker (Table 1.)

Table 2. Biochemical tests performed for confirmation of $X$. citri

\begin{tabular}{l|l|l}
\hline S.No & Test performed & Results \\
\hline 1. & Gram staining & Gram negative rod \\
2. & Catalase test & Positive \\
3. & Oxidase test & Negative \\
4. & O-F test & Oxidative \\
5. & Methyl-Red test & Negative \\
6. & Voges- Proskeur test & Negative \\
7. & Indole test & Negative \\
8. & Urease test & Negative \\
9. & Strach hydrolysis test & Positive \\
10. & Nitrate reduction test & Negative \\
11. & Growth on nutrient agar incorporated with $0.1 \%$ triphenyl tetrazolium chloride & No growth observed \\
12. & Growth at $37^{\circ} \mathrm{C}$ & Positive \\
13. & Acid production from carbohydrates (arabinose, glucose, & Acid production from \\
& galactose, fructose, sorbitol) & glucose, sucrose, mannose \\
& & and galactose \\
\hline
\end{tabular}




\section{Dynamics of disease development}

Dynamics of the disease development was studied on the basis of increase in disease severity in control plots sprayed with water in every 15 days interval.

\section{Efficiency of treatments}

Statistical analysis of data (LSD, at 5\% level of significance) (Table 3) showed that chemical sprays satisfactorily reduced the disease severity. Treatments had their effect immediately after use and continuously slowed down the disease development through out the rainy season as described by Koizumi (1985), Leite and Mohan (1990), Stall et al. (1980), (1982b) and Graham et al. (1992) who recommended copper-based bactericides as standard control measures for citrus canker world-wide. It was clearly observed that chemical treatments though effective could not control already existing lesions so the treatment should be started with the early sign of symptoms so that the disease spread can be slowed down or checked.

Copper hydroxide, basic copper chloride, copper oxychloride, and tribasic copper sulfate are the most effective bacterial sprays for protecting leaves and fruit from attack of $X$. citri. These materials can reduce the incidence of the disease, but they will not eliminate established infections. Copperoxychloride and kasugamycin have been used with satisfactory results. However, extensive use of copper may also cause phytotoxicity problems in treated groves (International citrus canker research workshop. 2000). The plants treated with Bordeaux mixture $2 \%$ showed symptoms of phytotoxicity. Therefore, Bordeaux mixture $2 \%$ may not be applicable to control the disease canker.

Table 3. Disease severity on first observation $(2063 / 2 / 27)$

\begin{tabular}{l|l|l|l|l|l}
\hline Replicates & Plot 1 & Plot 2 & Plot 3 & Plot 4 & Plot 5 \\
\hline 1 & $55 \%$ & $50 \%$ & $60 \%$ & $70 \%$ & $50 \%$ \\
2 & $60 \%$ & $70 \%$ & $60 \%$ & $65 \%$ & $70 \%$ \\
3 & $50 \%$ & $65 \%$ & $65 \%$ & $60 \%$ & $70 \%$ \\
4 & $58 \%$ & $65 \%$ & $70 \%$ & $70 \%$ & $65 \%$ \\
5 & $65 \%$ & $75 \%$ & $40 \%$ & $60 \%$ & $30 \%$ \\
\hline
\end{tabular}

(Observation after $3^{\text {rd }}$ spray) $(2063 / 5 / 15)$
Table 4. Disease severity on 5th observation

\begin{tabular}{l|l|l|l|l|l}
\hline Replicates & Plot 1 & Plot 2 & Plot 3 & Plot 4 & Plot 5 \\
\hline 1 & $53 \%$ & $51 \%$ & $53 \%$ & $72 \%$ & $75 \%$ \\
2 & $57 \%$ & $78 \%$ & $61 \%$ & $62 \%$ & $85 \%$ \\
3 & $52 \%$ & $67 \%$ & $61 \%$ & $61 \%$ & $85 \%$ \\
4 & $64 \%$ & $69 \%$ & $73 \%$ & $74 \%$ & $82 \%$ \\
5 & $68 \%$ & $75 \%$ & $44 \%$ & $57 \%$ & $59 \%$ \\
\hline
\end{tabular}

Table 5. Mean effectiveness of each treatment

Effectiveness $=$ Final disease severity $(5$ th observation i.e. after $3^{\text {rd }}$ treatment) - initial disease severity $\left(1^{\text {st }}\right.$ observation

\begin{tabular}{|c|c|c|c|c|c|c|}
\hline $\begin{array}{l}\text { Repli- } \\
\text { cates }\end{array}$ & $\begin{array}{l}\text { Plot1 } \\
\text { Coppero } \\
\text { xychloride } \\
(2.5 \%)\end{array}$ & $\begin{array}{l}\text { Plot } 2 \\
\text { Coppe } \\
\text { roxy } \\
\text { chloride } \\
+ \text { kasuga } \\
\text { mycin } \\
(1000 \mathrm{X})\end{array}$ & $\begin{array}{l}\text { Plot } 3 \\
\text { Bord } \\
\text { eaux } \\
(1 \%)\end{array}$ & $\begin{array}{l}\text { Plot } 4 \\
\text { Bord } \\
\text { eaux } \\
(2 \%)\end{array}$ & $\begin{array}{l}\text { Plot } 5 \\
\text { Control } \\
\text { (Water) }\end{array}$ & LSD* \\
\hline 1 & -2 & 1 & -7 & 2 & 25 & \\
\hline 2 & -3 & 8 & 1 & -3 & 15 & \\
\hline 3 & 2 & 2 & -4 & 1 & 15 & \\
\hline 4 & 6 & 4 & 3 & 4 & 17 & \\
\hline 5 & 3 & 0 & 4 & -3 & 29 & \\
\hline $\begin{array}{l}\text { Mean } \\
\text { effect } \\
\text { ivenss }\end{array}$ & $1.2^{\mathrm{b}}$ & $3^{b}$ & $-0.6^{b}$ & $0.2^{\mathrm{b}}$ & $20.2^{\mathrm{a}}$ & 5.81 \\
\hline
\end{tabular}

$*$ at $5 \%$ level of significance

On the basis of statistical analysis (LSD, at 5\%), it was found that all the treatments significantly reduced the rate of increase of the disease as compared to control.

The local varieties/cultivars of mandarin and sweet oranges were found resistant to citrus canker. The lime was very susceptible and special care has to be taken to control it with copper based chemical sprays. 


\section{Acknowledgement}

The authors are highly thankful to Nepal Academy of Science and Technology (NAST) for providing laboratory facilities and Mr. Lok Nath Deoju for providing his orchard for the research work.

\section{References}

Brunings, A.M. and D.W. Gabriel 2003. Xanthomonas citri: breaking the surface. Molecular plant pathology 4: $141-157$

Civerolo, E.L. 1984. Bacterial canker disease of citrus. Journal of Rio Grande Valley Horticulture Society 37: 127-146.

Graham, J.H., T.R. Gottwald, T.D. Riley and M.A. Bruce 1992. Susceptibility of citrus fruit to bacterial spot and citrus canker. Phytopathology 82: 452-1325

Gabriel, D.W., M.T. Kingsle, J.E. Hunter and T.R. Gottwald, T.R. 1989. Reinstatement of Xanthomonas citri (ex Hasse) and X. phaseoli (ex Smith) to species and reclassification of all $X$. campestris pv. citri strains. International Journal of Systemic Bacteriology 39: 14-22.

Johnston, A. and C. Booth. 1983. Plant Pathologists Pocketbook ( $2^{\text {nd }}$ ed). Commonwealth Mycological Institute, Kew, Surry, England pp. 23-28,

Koizumi, M. 1985. Citrus canker: The world situation. In: Citrus Canker: An International Perspective (Ed. L.W. Timmer), University of Florida, Lake Alfred pp. 2-7.

Leite, R.P., and S.K. Mohan. 1990. Integrated management of the citrus bacterial canker disease caused by
Xanthomonas campestris pv. citri in the State of Parana, Brazil. Crop Protection 9: 3-7.

Schaad, N.W. A.K. Vidaver, G.H. Lacy, K. Rudolph and J.B. Jones 2000. Evaluation of proposed amended names of several Pseudomonads and Xanthomonads and recommendations. Phytopathology 90: 20-213.

HMG/N, 2004/2005. Statistical information on Nepalese agriculture. His Majesty's Government of Agriculture and Co-operative. Agriculture-Business Promotion and Statistics Division, Singha Durbar, Kathmandu, Nepal pp. 1-47.

Stall, R.E., J.W. Miller, G.M. Marco and B. Canteros 1980. Population dynamics of Xanthomonas citri causing cancrosis of citrus in Argentina. Proceeding of Fla. state horticulture society 93: 10-14.

Stall, R.E., J.W. Miller, G.M. Marco and B. Canteros. 1982b. Timing of sprays to control cancrosis of grapefruit in Argentina. Proceedings of International society of citriculture 1: 414-417.

Stall, R.L. 1993. Canker In Compendium of citrus diseases (Eds. J.D. Whiteside, M. Garnsey, L.W. Timmer). The American Phytopathological society pp 6-7.

Vauterin, L., B. Hoste, K. Kersters and J. Swings 1995. Reclassification of Xanthomonas. International Journal of Systematic Bacteriology 45: 472-489.

Young, J.M., C.T. Bull, S.H. De Boer, G. Firrao, L. Gardan, G.E. Saddler, D.E. Stead and Y Takikawa 2001. Classification, nomenclature, and plant pathogenic bacteria. A clarification. Phytopathology 91: 617-620. 
Nepal Journal of Science and Technology 10 (2009) 